\title{
Problems in Raising Young Sandhill Cranes
}

\author{
By DAYTON O. HYDE, Yamsay Ranch, Chiloquin, Oregon
}

Four of the young which we raised on our ranch last year (1956) migrated in the fall, appearing on December 2 near Santa Rosa, California. There they were afraid of dogs as cranes would be in the wild, but they let people approach. This did not surprise us, as we had not tried to make them wary of people, since we were concerned merely with developing flight and intended to pinion the birds for the breeding flock. The four cranes were fed during the winter at an Air Base, which they left and returned to at will. Eventually they were trapped and taken to the Fleishacker Zoo in San Francisco. After eight months' absence from the ranch, they went wild with excitement when I appeared in the crowd at the zoo and gave them a low food call. I brought them home by auto where they immediately dashed for the spot where their parents spend most of their time.

Obviously, any Whooping Crane management programme would fail if birds raised in captivity could not be returned to the wild. I am not worried any more about flight powers or ability to feed in the wild. I think that we have solved the problem of developing these. The real stickler is to raise young cranes so that they don't regard Man as a benefactor, so that they become truly wild. This year we raised two young without their ever seeing man-behind panels which gave them a one-way view over the meadows and marshes. We developed a method of feeding eliminating hand feeding, which I didn't dream was possible since even the wild parents feed the young with their beaks.

All went well until the third week, when the older and larger of the two turned on the other and almost killed him. After hours under a heat lamp, the younger crane regained consciousness, but it still shows the effects of the beating, having developed pneumonia. We are caring for it by hand and once more it is growing fast. Because this little crane remains as wild as any in the field, I suspect that, once the time of imprinting is past, it is hard to condition a young crane to regard Man as his benefactor as did my handraised cranes of last year. I hope to determine the exact length of time cf imprinting. If we find this time to be only a short interval, it would simplify my programme anc methods.

I have spent many hours in the field this year trying to determin just why the wild Sandhills usually raise only one young. In the $\mathrm{Bl}$ ! valley of southern Oregon I checkes five pair with two young, one witr one young. Two young ran with eacl pair from a week to a month, longe than my previous records. In a late survey by helicopter we found tha none of the pairs had more than on young left, although all had on This loss is difficult to explain is terms of predation. The pilots o two helicopters became very inter ested in our cranes and since the spent many days over the nestin areas, they checked every pair the found. I went with them on sever: flights and found their observation correct-only one chick with eac pair.

When I have seen two young birc with a pair, the general patter seems to be this, that the male taki one chick and the female the othe generally feeding from one to th hundred feet apart. If an alien crar intrudes, the male flies up and driv the intruder out of the territory. $\mathrm{Tr}$ chick leaves the male to go to i mother, but when the male com back trom his flight, the chick joil its father again. Perhaps this obse vation will prove of use if Whoopis Cranes are raised in captivity. O chick might be removed and given the second parent, without deprivil them of sight contact with ea other, at least during the daylig hours. Crane research is a slow, la orlous process and there is still $\mathrm{mu}$ to be learned. 